\title{
CLASSIFICATION OF HIGH EARTHQUAKE RISK BUILDINGS
}

Draft Code of Practice, 2 March 1972

A. Background notes By O. A. Glogau (Chief Structural Engineer, Ministry of Works.)

In 1968 the Municipal Corporation Act of 1954 and the corresponding Counties Act were amended thus giving more positive powers to councils "with respect to buildings likely to be dangerous in earthquake".

Acts of Parliament are not and cannot be precise engineering documents and the need for guidelines on the technical criteria and the procedures on priorities to be used in implementing the legislation was obvious to all concerned from the start. As a result of a resolution at the 1969 A.G.M. the society decided to set up a steering Committee to investigate the possibility of producing a "Code of practice for the classification of high risk buildings". Shortly thereafter the Minister of Internal Affairs requested the Standards Association of New Zealand to prepare guidelines for the investigation of high risk buildings. The New Zealand Standard Association while unable to undertake this task themselves have offered to co-operate with the Society and to assist, i.e. with the publication of material resulting from their project.

The steering Committee formed by the Society, was aware that this was a task beyond the time resources available to volunteers engaged in other full time activities, and encountered considerable difficulties in finding an individual suitably qualified and with sufficient time available to undertake this task. Thus it was not until late 1969 that the society was able to engage Mr. I. C. Smith to prepare a preliminary report and cost estimate. Finance for the project could not be arranged until July 1970 with two-thirds of the cost being borne by the New Zealand Earthquake and War Damage Commission and one-third by the Building Research Association of New Zealand.

Mr. Smith in producing several drafts for the Committee was able to draw on the experience in this field of the New Zealand Ministry of Works who had been engaged in the systematic classification for removal or strengthening of dangerous Government owned and leased buildings for over 10 years and had developed a classification system of their own suited to their particular requirements (1).

A few general comments on the Act may be appropriate here. Firstly, the legislation does not apply automatically. It applies only to those cities and boroughs that have made an application to the Minister and have been granted the special powers by order in Council. Before recommending an application the
Minister must be satisfied that the council has a person on the staff or will engage a person suitably qualified and experienced in the investigation of earthquake risk buildings.

Many more buildings than are at present covered by the Act are likely to be dangerous in an earthquake. The Act applies only to unreinforced masonry buildings as defined in this group and only to those that have their "ultimate strength exceeded when subjected to one-half code level forces".

Recent dynamic tests on modern reinforced masonry have indicated that ductile flexural overload performance is extremely difficult to achieve even where static reversed loadings tend to indicate favourable conditions for that type of failure (2). Thus even with modern forms of masonry the structure must be designed to withstand forces several times the code specified values which have proved satisfactory design loads for ductile frame structures, i.e. the ductility demand must be kept at a very low level. Unreinforced masonry has no ductility and its only line of defence is its inherently greater damping property and hopefully in some instances - fairly generous dimensions that allow rocking of parts when static considerations only would indicate overturning. This does not mean that the writer advocates, or interprets the Act as intending complex investigation procedures. As is borne out by the results of testing and investigation of modern masonry construction sophisticated methods rarely provide more realistic answers than the very approximate approach. Additionally, damping is of little help to very rigid structures so that the situation exists where some of the stiffest masonry buildings will be subjected to near elastic response, i.e. 40-50 per cent "g" accelerations in an El Centro type disturbance. Even so buildings acceptable under the definition of the Act will have a statically computed resistance of only $6 \% \mathrm{~g}$ in zone $\mathrm{A}$.

Clearly then a higher level of earthquake resistance is desirable, however considering the large number of low strength unreinforced masonry buildings in this country, in practical terms it will not make much difference for many years to come if for the present our target strength is low. Not until substantial progress with the removal or strengthening of this group of buildings - which have typically in the past been responsible for the greatest losses in human life due to the vibratory effects of earthquakes - will it be an advantage to raise the level of "moderate earthquake" and widen the scope of "building". I suspect that by then we might have to include some of our more recent framed multistorey building not adequately 
designed and detailed for ductility (and not containing reserve energy providing walls) and reinforced masonry shear wall buildings designed to current code levels, etc, under "likely to be dangerous".

Because of the financial limitations on the project a decision had to be made on which aspects of the project to concentrate the major effort. With a number of councils already carrying out preliminary classifications of buildings using a variety of approaches it was considered adviseable to make immediate recommendations with regard to this phase of classification. Much less guidance is given to other aspects, e.g. it was hoped at one stage to produce sample calculations on the ultimate strength of typical dangerous buildings but it soon became obvious that this was too ambitious an undertaking at this stage.

What is the likely effect then of the Act and the assistance provided by this document?

1. Hopefully more councils will apply to be given the powers available under the Act.

2. Removal of "particular hazards" such as gables, chimneys, etc., should be accelerated. Some of these have already been removed in the more earthquake conscious cities of this country.

3. The modernisation of hazardous buildings which would extend their 1 ife without significant strengthening will be avoided. This is one of the most important aspects of the Act and it is often overlooked that in these cases a building has to be "secured to the satisfaction of the Council". The level of securing considered satisfact. ory is a matter for the council to decide and usually is set much higher than "ultimate strength at the one-half code forces". In return the building is usualiy given an extended period of "life" depending on the degree of strengthening. Considering the significant tax write offs owners are allowed for strengthening, this approach makes sense all round.

Because of the economic pressures at work the concern felt by some on the limited guidance given in the document on the determination of "ultimate strength" is then in practice much less of a real shortcoming than would appear to be the case at first sight and it will continue to be so if the present reasonable attitude to the problem by all concerned prevails.

The document is therefore expected to be of considerable value to those faced with the task of determining in a reasonably short time the relative risk of old masonry buildings and should ensure essentially uniform results by standardising the evaluation procedures.

\section{REFERENCES}

(1) "Seismic Classification System for 01d Building $s$ in New Zealand". C. M. Strachan, Proceedings of the IV World Conference on Earthquake Engineering, Santiago, Chile 1965 .
(2) D. Williams, Ph.D. Thesis, University of Canterbury 1971.

B. Draft Code of Practice - Compiled by I. C. Smith (Partner, Brickell, Moss, Rankine and Hill), with final draft by Sub-Committee of New Zealand Society for Earthquake Engineering.

\section{PRELIMINARY}

\subsection{Introduction}

The following draft is presented as a guide for local authorities concerned with the implementation of section $301 \mathrm{~A}$ of the Municipal Corporations Act, 1954, and Clause 318 A of the Counties Act 1956.

In presenting these recommendations the Society has interpreted the Act in a manner which it believes to be the Act's intention. Council should obtain legal advice where there is room for varying interpretation. The Society's recommendations suggest a priority approach to the removal or securing of hazards for those buildings which have been shown to constitute an earthquake hazard under the Act.

\subsection{Definitions}

The definition of terms used in this draft are as those given in the Act; a copy of the Act is included at the end of this article.

\section{STRUCTURAL SURVEY OF BUILDINGS}

2.1. General

It is proposed that a structural survey be carried out of all buildings coming within the definition given in the 1968 Amendments to the Municipal Corporations Act and the counties Act.

\subsection{Purpose}

The purpose of the survey is to obtain, in a relatively short period of time, a reasonably correct picture of the relative risk of all $10 \mathrm{w}$ earthquake resistant buildings defined in the Act, so that detailed examinations in accordance with Clause 7 can be carried out in the correct order of priority, to determine those buildings or parts of buildings which come under the act.

\subsection{Priorities}

Buildings that are potentially the greatest risk to the greatest number of people in and around them or which are of the greatest importance to the community, particularly following an earthquake, should be surveyed first, $i . e$. building s wich are used as places of assembly or any other building that has a high density of occupation such as a theatre, departmental store or supermarket. The risk increases with the length of occupation. Twenty-four hours of occupation for seven days represents a far greater risk to a given number of occupants than a building occupation of only eight hours a day for five days. Buildings of particular importance following seismic disaster would include fire stations and any building used or likely to be required 
by Civil Defence; these should be given priority. Also buildings whose collapse could block essential services. Special consideration may be given to historic buildings.

\subsection{Programme}

Target dates should be established at which the various stages of the survey are to be completed. Council staff should be made available to meet those targets and supplemented where necessary by qualified personnel from private enterprise, The full survey should be completed by the beginning of a base year, say 1975.

\section{PARTICULARLY HAZARDOUS BUTLDINGS}

\subsection{General}

With the group of buildings mentioned in 2.3 above, certain structural types will, as a rule, present the greatest hazzard and should be dealt with first. These are the multi-storey buildings with weak mortar, inefficient craming or ineffective diaphragms or connections and few crosswalls. In the more active seismic regions most of these buildings will have been weakened by earthquakes.

other particularly hazardous buildings are those with weak lower floors such as buildings having bracing walls along two exterior faces only or more generally having a resisting system subjected to large torsions, but unable to provide torsional resistance. Al so buildings with few stiff elements in the lower floor in general, or buildings with part height panels between some columns attracting high shears to local areas.

\subsection{Floating Diaphragms}

Floating floors and roofs which require the higher levels of walls to cantilever one or more storeys, give rise to wall failures and ultimately the collapse of the floor supported. If failure is to be avoided in even a moderate earthquake, adequate ties must be installed to connect diaphragms to walls.

\subsection{Concrete Floors}

Buildings with concrete floors (despite the possible contribution to diaphragm action) result in high casualties in case of collapse. It is recommended that concrete Floors be provided with an independent supporting system so that in the event that load bearing walls should fall out, the floors will not collapse.

\subsection{Highly Loaded Buildings}

Many cases exist where floors are loaded far in excess of a normal, average rate per square foot of building. Total building loadings should be limited to a reasonable figure consistent with the building condition.

\subsection{Miscellaneous}

other features which have given rise to failures in old masonry buildings are :
1. Walls of theatres and similar structures which are overlong or overtall with indifferent lateral support.

2. Buildings with party walls to which floors are attached at different levels on two sides.

3. Extensive glass facades in one, two or three walls without compensating bracing features. This is particularly serious where present in the lower storey.

4. Constructional defects such as weak mortar joints, unbonded corners or wall intersections - Damp proof courses at critical sections.

5. Loss of mortar joint tensile strength due to moisture movement or previous excessive loadings.

6. Unbonded additions and weakening affects of alterations or "modernising" treatments.

7. Unsymmetrical plan and elevation treatment: U-shaped or L-shaped buildings.

8. Abnormal slenderness in one direction.

9. Tower-1ike appendages.

10. Soils likely to be severely disturbed by an earthquake.

\section{PARAPETS, GABLES AND CHIMNEYS}

Particular hazards such as parapets, gables, chimneys, etc., are as a rule simpler structures and can be dealt with independently of the main structure and with less effort and expense to the owner. Highest priority should be given to the location and removal of these hazards and their removal when non compliance with the Act (refer ch. 7) can be shown.

\section{CLASSIF ICATION}

5.1. Introduction

In view of the large number of buildings in relation to the available survey teams, a simple system is essential; a system that should serve at least as an initial guide in establishing the buildings which come within the Act: these would then be confirmed using the methods given in Clause?.

It is recommended that an overall period be estabilished over which removal or strengthening of all buildings not complying wi th the Act shall be carried out in accordance with their classification. The length of iffe evaluated may vary from Council to Council and should be related to a number of factors, one of which could be the seismicity of the locality. Allowance should be made for the time it will take to complete the classification, and give a period for removal or strengthening related to that date as a base year, e.g. a Council may decide to remove all Type 1 buildings in 20 to 24 years from 1975.

The following classification is proposed:

\subsection{Building Classification}

The lettering system used is fairly arbitrary, but has the merit of being identical to that used for some 15 years by the Ministry of Works. The letter $M$ stands for buildings 
having unreinforced masonry or concrete walls. This is at present the only type of building covered by the Act, but it is possible that in future years other $10 \mathrm{w}$ earthquake resistant types of buildings will be included in the Act and a material identif ication will then be required.

\subsubsection{Class MA}

Masonry buildings which should be evacuated and demolished immediately because they constitute a potential hazard in the event of earthquake of intensity much lower than moderate. Buildings of this type are likely. to be a hazard in the event of wind storm.

\subsubsection{C1ass MB (i)}

Masonry buildings which have particular hazards such as those listed in section 4 above and which are liable to damage in the event of an earthquake. (Particular hazards should be removed as soon as possible.)

Class MB (i) buildings on removal of ha $\mathrm{ards}$ shall be reclassified into one of the divisions of Class MC.

\subsubsection{Class MB (ii)}

Masonry buildings with concrete floors supported on unreinforced masonry walls (these buildings shall be strengthened as soon as possible or an independent supporting system installed).

Class MB (ii) buildings on completion of strengthening measures shall be re-classified into one of the divisions of Class MC.

\subsubsection{Class MC}

This class comprises all low-earthquake resistant masonry buildings not qualified for immediate evacuation and not requiring remedial treatment.

As most old buildings fall into this class it should be sub-divided into six sections and numbered from 0 to 5 in order of decreasing risk. To ensure uniformity in sub-classification the system of penalties shown in Table I should be applied to each building according to structure, structural condition, number of storeys, structural damage, type of wall, effectiveness of diaphragms; and the nature of the sub-soil.

The total penalty should determine the appropriate sub-division of Class MC. Thus buildings with the greatest number of penalties are classified MC (1) and the least number MC (5).

\subsubsection{Life Evaluation or Strengthening Period}

The following periods are suggested for Types 1 and 2 buildings falling within the provisions of the Act during which they must be strengthened to the Councils' satisfaction or demolished, according to the number of demerit points derived from Table $I$. Councils may place buildings located close to high density traffic or pedestrian ways (1ikely to block important access routes) into a special category and give a reduced ife assessment. (Refer Table II)

\section{STRENGTHEN ING}

6.1. General

Buildings which fall within the provisions of the Act must be removed or secured to the Council's satisfaction. Council having advised the owner of the buildings life evaluation may agree to extend this life subject to the extent to which the owner is prepared to secure it. It will rarely be economically feasible to strengthen a building to the extent that it will comply with the letter and spirit of the current loading code, i.e. survive a major earthquake.

\subsection{Minor Strengthening}

Minor strengthening is aimed at reducing the risk of total collapse due to a particularly hazardous feature of a building. This may take the form of :-

(a) The installation of ties to make diaphragms effective.

(b) The installation of an independent support system for heavy concrete floors.

(c) The removal of load on overloaded floors.

(d) The provision of lateral support to unbraced walls.

(e) The provision of additional ties (by prestressing or by construction of skin walls) to areas damaged in previous earthquakes.

(f) The installation of bracing to compensate for extensive glass facades.

Or other modification which does not substantially effect the overall strength of the building.

\subsection{Major Strengthening}

The full strengthening of a building would in addition to inor strengthening given in 6.2 involve one of the following. :-

(1) The provision of a reinforced concrete encasement around the entire structure or

(2) The provision of rigid corseting with members fully tied into the masonry.

Such additional structure should be sufficient to bring the combined strength (masonry plus reinforced concrete) close to the present code requirements.

\section{DETERMINATION OF ULTIMATE STRENGTH}

\subsection{General}

The following is a general description of the approach used by many engineering offices: It is believed that a very approximate approach will give as good results as refined techniques because of the inadequacy of engineering data that can be obtained from an old masonry building. Neither does it appear to be the intent of the legislation that complex methods should be used. The non dynamic approach will be severe in assessing 


\begin{tabular}{|c|c|c|c|c|}
\hline \multicolumn{5}{|c|}{ TABLE } \\
\hline \multicolumn{5}{|c|}{ TABLE OF PENALTIES } \\
\hline & 0 & PENAL & TIES 2 & 3 \\
\hline I. & & $\begin{array}{l}\text { Unreinforced } \\
\text { masonry with } \\
\text { reinforead concrete } \\
\text { wall bands at } \\
\text { floors at root. }\end{array}$ & & $\begin{array}{l}\text { Unreinforced } \\
\text { conerete or masonry } \\
\text { without ties or } \\
\text { concrete bonds. }\end{array}$ \\
\hline $\begin{array}{l}2 . \\
\text { Structural } \\
\text { Condition }\end{array}$ & $\begin{array}{l}\text { Structure well } \\
\text { made materials } \\
\text { in sound condition } \\
\text { COOD }\end{array}$ & $\begin{array}{l}\text { Poor workmanship; } \\
\text { some evidence } \\
\text { of deterioration } \\
\text { of materials } \\
\text { FAIR }\end{array}$ & $\begin{array}{l}\text { Obvious daterioration } \\
\text { of mortar, fretting } \\
\text { of concrete, and } \\
\text { rusting or losening } \\
\text { of connections. } \\
\text { POOR }\end{array}$ & \\
\hline $\begin{array}{l}3 . \\
\text { Number of } \\
\text { storeys or height } \\
\text { of external walls }\end{array}$ & Up to $20^{\prime}$ & $\begin{array}{c}\text { Two } \\
20^{\prime}-30^{\prime}\end{array}$ & $\begin{array}{l}\text { Two to Four } \\
30^{\prime}=50^{\prime}\end{array}$ & $\begin{array}{l}\text { More than Four } \\
\quad \neq 50^{\prime}\end{array}$ \\
\hline $\begin{array}{l}4 \text { Structural } \\
\text { Damage }\end{array}$ & $\begin{array}{l}\text { No damage } \\
\text { evident } \\
\text { NONE }\end{array}$ & $\begin{array}{l}\text { Settlement cracking } \\
\text { but no evidence } \\
\text { of cracking due } \\
\text { to carthquake } \\
\text { SETTLEMENT }\end{array}$ & $\begin{array}{l}\text { Some minor } \\
\text { cracking attributable } \\
\text { to earihquake } \\
\text { MINOR }\end{array}$ & $\begin{array}{l}\text { Considerable } \\
\text { cracking due to } \\
\text { carthquake } \\
\text { SEVERE }\end{array}$ \\
\hline 5. Walls $*$ & $\begin{array}{l}\text { Cross walls at } \\
\text { less than } 2 O^{\prime} \\
\text { centres } \\
\text { WELL BRACED }\end{array}$ & $\begin{array}{l}\text { Cenerally supported } \\
\text { by crosswalls but } \\
\text { some areas with } \\
\text { walls }>30^{\prime} \text { long } \\
\text { PARTIALLY } \\
\text { BRACED }\end{array}$ & $\begin{array}{l}\text { Long walls generally } \\
\text { but horizontal } \\
\text { diaphragms(floors) at } \\
\ngtr 15 \text { ' centres } \\
\text { NOT BRACED VERT. }\end{array}$ & $\begin{array}{l}\text { Long high walls } \\
\text { without lateral } \\
\text { support } \\
\text { (n excess } 30 \text { 'iong } \\
\text { by } 15^{\prime} \text { high) } \\
\text { NOT BRACEO IN } \\
\text { EITHER DIRECTION }\end{array}$ \\
\hline Diaphragms & $\begin{array}{l}\text { Concrete slab or } \\
\text { equivalent odequately } \\
\text { supported on framing } \\
\text { which itself is } \\
\text { designed to withstand } \\
\text { eartheuake and is. } \\
\text { adequately tied to } \\
\text { walls } \\
\text { EFFECTIVE } \\
\end{array}$ & $\begin{array}{l}\text { Concrete slab or } \\
\text { equivalent adequately } \\
\text { supported on traming } \\
\text { which itself is } \\
\text { designed to } \\
\text { withstand earthequake } \\
\text { EFFECTIVE }\end{array}$ & $\begin{array}{l}\text { Heavy himber } \\
\text { section designed } \\
\text { with engineering } \\
\text { connections and } \\
\text { well tied into the } \\
\text { exterior wall. } \\
\text { PARTIALLY } \\
\text { EFFECTIVE }\end{array}$ & $\begin{array}{l}\text { Light timber with } \\
\text { carpenters connections } \\
\text { at framing and at } \\
\text { outer walls. }\end{array}$ \\
\hline $\begin{array}{l}7 . \\
\text { Foundations } \\
\end{array}$ & EXCELLENT & $\begin{array}{l}\text { Well graded firm } \\
\text { sands or gravels } \\
\text { or firm clays } \\
\text { silts. }\end{array}$ & $\begin{array}{l}\text { Soft clays silts } \\
\text { loose sand's well } \\
\text { graded or firm } \\
\text { fill maierial } \\
\text { FAIR }\end{array}$ & $\begin{array}{l}\text { Uniform sands or } \\
\text { loose fill material } \\
\text { or reclamation. }\end{array}$ \\
\hline
\end{tabular}

In assessing penalty points for structure, consider also the plan shape and the distribution of mass in elevation. Add an extra point for $U$ or $L$ shaped buildings or for buildings having extensive glass facades in one, two or three walls without compensating bracing features. In the extreme case of a building with little st rength at a lower floor (even when the structure is otherwise well proportioned) add further points to ensure replacement as soon as possible.

Where exterior walls are comparatively thin or of cavity type construction, allow a greater penalty.

- In assessing foundations, recognition should be made of an adequate system of foundation ties.

Thus buidings on marginal ground between categories would be rated in the higher category if the

foundations are tied. 
$\underline{\text { TABLE II }}$

CLASSIFICATION AND PROPOSED LIFE EVALUATION

OR STRENGTHENING PERIOD (IN YEARS)

\begin{tabular}{|c|c|c|c|r|}
\hline $\begin{array}{c}\text { Classifi- } \\
\text { cation }\end{array}$ & $\begin{array}{c}\text { Number of } \\
\text { Penalties }\end{array}$ & \multicolumn{2}{|c|}{$\begin{array}{c}\text { Review } \\
\text { Period }\end{array}$} & \multicolumn{2}{|c|}{$\frac{\text { Life Evaluation in Years }}{\text { Type } 1}$} \\
\hline A & $18-20$ & 0 & $0-4$ & $0-6$ \\
C1 & $15-18$ & 1 & $4-8$ & $6-12$ \\
C2 & $12-15$ & 2 & $8-12$ & $12-18$ \\
C3 & $9-12$ & 3 & $12-16$ & $18-24$ \\
C4 & $6-9$ & 4 & $16-20$ & $24-30$ \\
C5 & $0-6$ & 5 & $20-24$ & $30-36$ \\
\hline
\end{tabular}

* Multiply number of years by factor $K$ where $K$ is a factor selected by an individual Council to suit local conditions. In selecting $K$, it is recommended that consideration be given to the serious cumulative effect frequent damaging earthquakes have on unreinforced masonry.

Notes :-

1. The proposed time for removal or strengthening is calculated by adding the number of years from Table II, multiplied by factor $K$, to the base year, say 1975. e.g. A Type 2 building classified as $C 2$ should be removed in from $\left(\begin{array}{llll}0.8 & 12\end{array}\right)$ to $(0.8 \times 18)$ years or between 1985 and 1990 , when $K=0.8$.

2. Regular structural inspections should be made during the period given for strengthening or demolition. Review period is the interval in years to the next structural inspection.

3. Building $s$ are placed into type 1 and 2 depending on density of occupation or importance to the community.

Refer to Appendix A. 
the strength of some parts of a building such as parapets, but they do represent major hazards and the loading code was deliberately intended to be severe here. Their removal, compared to general strengthening, involves a relatively low cost.

\subsection{Seismic Design Forces}

The seismic design forces to be used in the calculation of ultimate stresses follow directly from the definition in the Act of a moderate earthquake. Hence use a seismic coefficient of half that specified in NZSS 1900 Chapter 8 (1965) and calculate forces and their distribution as set down in clause 8.36 of that code.

\subsection{Tensile Strength of Brickwork}

Unreinforced masonry with unconfined boundaries depends to a great degree on its tensile strength for resistance to horizontal forces. This property can, however, vary not only from one building to another, but from one part of a building to another part of the same building. In addition, weak mortar joints can give rise to planes of weakness. Unless it can be established by the building owner by means of a large number of samples taken from the building that a bond strength exists, the bond strength to be used in calculation of ultimate strength shall be zero. Stability of the structure will then depend on the pre-compression due to gravity loads.

\subsection{Diaphragms}

Where the ultimate strength of a building depends on the action of a timber or concrete floor to distribute force as a diaphragm to cross or end walls, the strength of the diaphragm shall be verified by calculations. The degree of nailing is the most significant parameter in the strength of a diaphragm.

Walls shall be tied to diaphragms by strapping or other fixing capable of both direct and shear forces where these are applicable.

Where ties are installed by bolting through a wall, adequate anchor plates to distribute the point load along the wall shall be provided.

\subsection{Walls}

Where load bearing walls are supported by diaphragms spaced widely apart, the inplane stresses between the diaphragms shall be calculated to check for vertical bending failure. The siesmic co-efficient to be used shall be the full co-efficient for the seismic zone.

Where walls are lightly perforated, forces may be assumed to follow inclined compression strut paths through spandrels. In some critical areas it may be necessary to consider the simultaneous stresses produced by in plane and face loadings.

\subsection{Analysis of Seismic Resisting Elements}

The strength of the vertical elements resisting horizontal force shall be calculated for each level. A total strength at any level shall be taken as the sum of all the strengths of all the individual elements.

The building shall be deemed to comply with the Amendment of the Act if the accumulated horizontal strength of all elements exceeds the calculated seismic force at all levels. Due account shall be taken in this calculation for out of balance of stiffness of the various elements.

\section{METHOD OF IMPLEMENTATION}

\subsection{Council Survey}

Councils shall be responsible for carrying out a survey of buildings within their area which fall within the definition of the Amendment to the Municipal Corporations Act. The stages of the survey shall be as follows :-

1. An initial survey to pinpoint buildings with the particular hazards noted in section 4. Owners of these buildings should be notified immediately and instructed to remove them within a very short specified time.

2. A more detailed survey carried out to provide information for the classification of all buildings, in accordance with the recommendations of clause 5. Then using the priorities thus obtained investigate in accordance with clause 7 to establish those buildings falling within the provisions of the Act. A list of these buildings would be complied and made available for public inspection. Building owners would be notified of the classification and told when their building must be removed or secured to the Councils satisfaction. (See Appendix $B$ for detailed inspection record form.)

3. A continuing survey to give reassessment of classified buildings where owners are prepared to strengthen or improve their buildings as described in section 6 . Provision is made here for the reclassification of a building to a higher category where strengthening is carried out and a longer period allowed for removal or its elimination from removal al together consequent on its meeting the ultimate strength requirements of the Act.

\subsection{Review Period}

It is recommended that after the initial survey and classification, further inspections shall be carried out at regular programmed intervals. The interval or review period for a particular building shall be gauged on the life evaluation. A period of life evaluation to the

nearest year is suggested. i.e. for a twentyfour year life evaluation, reviews should be carried out at four year intervals.

\subsection{Building Alterations}

No significant structural modifications shall be allowed without re-classification of a building or alternatively investigation of its ultimate strength. In addition, renovation which is of a substantial nature and is intended for a 1 ife in excess that established for the building shall not be allowed unless the building is strengthened as set down in section 6 . 
APPENDIX A

Buildings are placed into Types 1 or 2 depending on density of occupation or importance to the community.

Type 1

Hote 1

Theatre

Cinema

$\mathrm{Ha} 11$

Dance Hall

Bal1 Room

Fire Station

Hostel

Flats

Departmental store
Supermarket

Hospital

School

Library

Kindergarten

Spectator stand

Stores for Dangerous Materials

Buildings Housing Important Records

\section{Type 2}

Smal1 Shop

Restaurant

Offices

Art Gallery

Museum

Workroom

Church

Garage

Factory

Warehouse
Stores for Goods Auction Rooms

Drill Halls

Gymnasium

APPENDIX B

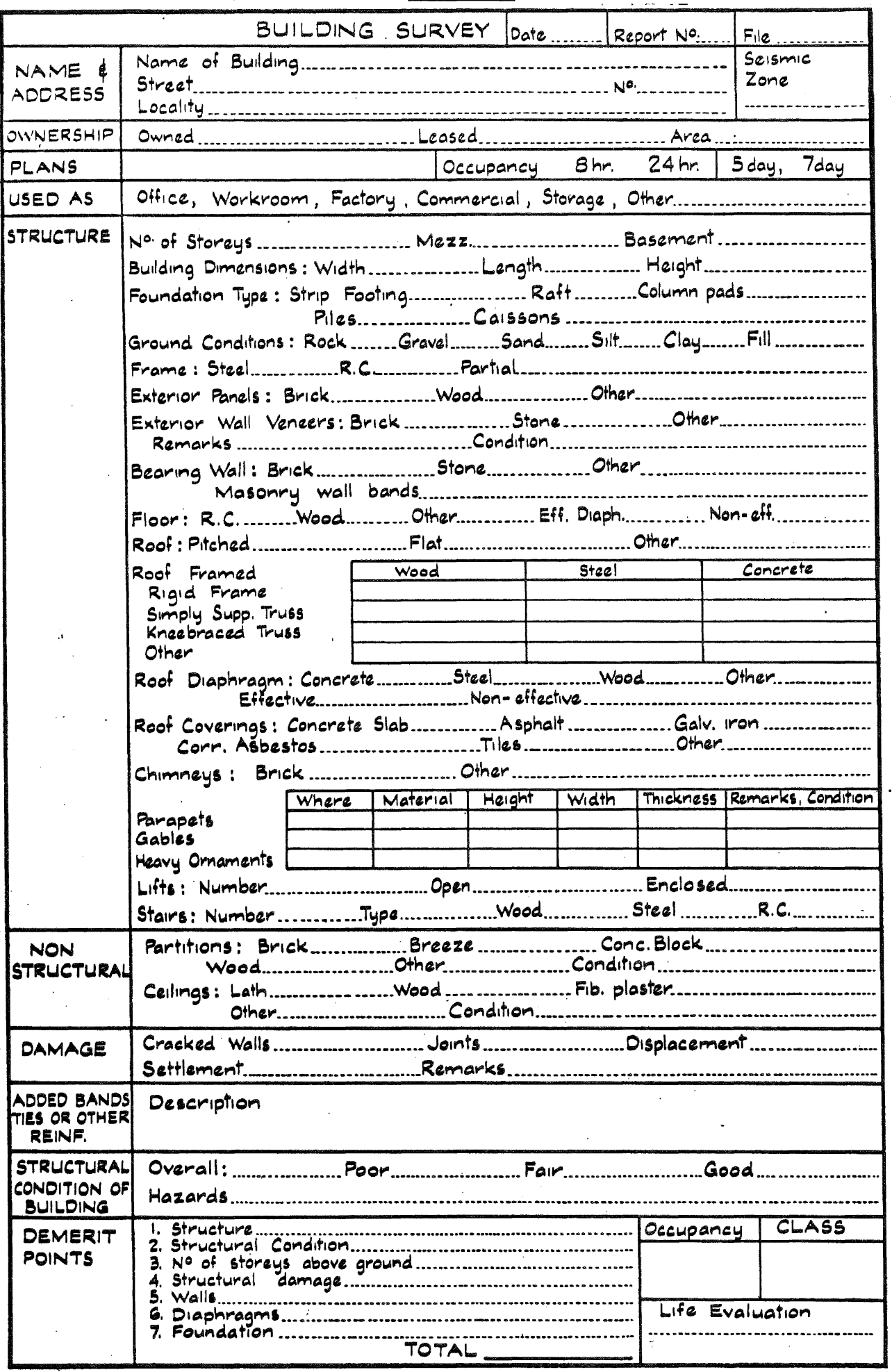




\section{Municipal Corporation Act 1954}

[301A. Powers of Council with respect to buildings likely to be dangerous in earthquake -(1) In this section -

"Building" means a building constructed wholly or substantially of unreinforced concrete or unreinforced masonry; and includes any part of a building so constructed; but does not include any building used wholly or principally as a private dwelling, unless the building is of two or more storeys and contains three or more residential flats or apartments:

"Council" means a Council to which this section applies pursuant to an Order of Council under subsection (2) of this section:

"Masonry" means any construction in units of burnt clay, concrete, or stone laid to a bond in and joined together with mortar:

"Moderate earthquake" means an earthquake that would subject a building to seismic forces onehalf as great as those specified in New Zealand Standard Model Building Bylaw (N.Z.S. 1900, Chapter 8: 1965) for the zone (as described in that bylaw) in which the building is situated: "Unreinforced masonry" means masonry classified as unreinforced masonry by Chapter 9.2: 1964 of the said bylaw.

(2) The Governor-General may from time to time, by order in Council made on the application to the Minister by the Council concerned, declare that any specified Council shall be a Council to which this section applies.

(3) Where the Council is satisfied that any building in the district (being a building to which this section applies), having regard to its condition, the ground on which it is built, its present and likely future use, and all other relevant matters, will have its ultimate load capacity exceeded in a moderate earthquake and thereby constitute a danger to persons therein or in any adjoining building or on any adjoining land or to passers-by, the Council may, by notice in writing signed by the Mayor or Chairman, as the case may be, or by the Town Clerk or Engineer given to the owner, require the owner of the building within the time specified in the notice to remove the danger, either by securing the building to the satisfaction of the Council or by taking down the building. The Council shall also send a copy of the notice.

(a) To every person having a registered interest in the 1 and on which the building is erected under any mortgage or other encumbrance; and

(b) To every person claiming an interest in the land which is protected by a caveat lodged under section 137 of the Land Transfer Act 1952 and for the time being in force; and

(c) Where the owner is not the occupier of the land within the meaning of the Rating Act 1967, to every occupier of the land within the meaning of that Act.

(70) 1969 p.2622

S.301A REFER: The index in the latest bound volumes of Regulations under the title "Municipal Corporations (Earthquake Dangers) order" for the orders which have. declared councils.
(4) Within 60 days after the notice is given to him, the owner or any person referred to in paragraphs (a) to (c) of subsection (3) of this section may object in writing to the Council against the requirements of the notice, and the notice shall thereupon be deemed to be suspended pending the determination of the objection, or, where application is made to the Court to confirm the notice, pending the decision of the Court.

(5) Where any such objection is received by the Council, the Council shall as soon as practicable inquire into and dispose of the objection:

Provided that no objection shall be dismissed unless reasonable notice of the date and time when and the place where it is to be considered has been given to the objector, who, if present at the appointed time and place, shall be entitled to be heard and submit evidence and call witnesses in support of his objection. Any objector may be represented at the hearing by counsel or otherwise.

(6) Where on inquiry into the objection the Council reaffirms its requirements, the 'Council shall apply to a Magistrate's Court for an order confirming the notice given by the Council under subsection (3) of this section.

(7) The Minister shall from time to time, by notice in the Gazette, publish a panel of persons of special skill or knowledge from whom assessors may be appointed under subsection (8) of this section.

(8) The Court hearing an application under subsection (6) of this section shall hear the application with the assistance of two assessors, to be appointed for the purposes of that application by the Secretary for Internal Affairs from the panel of persons published under subsection (7) of this section. The sole function of the assessors shall be to assist the court in determining the application, and the application shall be determined by the Court alone.

(9) If any assessor dies or is for any reason unable to act or to continue to act, an assessor may be appointed under subsection (8) of this section to act in his place, whether or not the hearing of the application has commenced.

(10) There shall be paid to assessors appointed under subsection (8) of this section, out of money appropriated by Parliament, remuneration by way of fees or allowances and travelling allowances or expenses in accordance with the Fees and Travelling Allowances Act 1951, and the provisions of that Act shall apply accordingly as if those assessors were members of a statutory Board-within the meaning of that Act.

(11) On the hearing of the application, the Court may -

(a) Confirm the notice without modification; or

(b) Confirm the notice subject to modification; or

(c) Extend the time specified in the notice for removing the danger: or

(d) Set aside the notice.

(12) Where - 
(a) In any case in which no objection is made, the owner fails to do any act in compliance with the notice given under subsection (3) within the time specified in that notice; or

(b) In any case in which objection is made, the notice is confirmed by the court (whether with or without modification or extension of time), and the owner fails to do any act in compliance with the notice or with the notice as modified or extended, as the case may be, -

the Council may enter upon the land and do that act and recover the cost thereof from the owner.

(13) The said cost shall be a charge on the land.I

This section was inserted by $s .22$ of the Municipal Corporations Amendment Act 1968.

As to earthquake dangers, see S.R. 1969/103, S.R. $1969 / 204$, and S.R. $1970 / 149$.

Permission has been obtained from the Government Printer to reproduce Section $301 \mathrm{~A}$ of the Municipal Corporations Act 1954.

Readers are invited to submit written comments on the draft code of Practice. 